\title{
Impact of arachidonic acid enrichment of live rotifer prey on bacterial communities in rotifer and larval fish cultures
}

\author{
Laurent H. Seychelles ${ }^{a}$, Kim Doiron ${ }^{b}$, Céline Audet ${ }^{b}$, Réjean Tremblay ${ }^{b}$, Fabrice Pernet ${ }^{c}$, \\ Karine Lemarchand ${ }^{\mathrm{b},}$
}

\footnotetext{
a Phytopathology Institute, Working group in aquaculture, Kiel University, Olshausenstraße 40-60, 24118 Kiel, Germany.

${ }^{\mathrm{b}}$ Institut des sciences de la mer de Rimouski, Université du Québec à Rimouski, 310 allée des Ursulines, Rimouski, QC G5L 3A1, Canada.

c Ifremer, UMR LEMAR 6539 - Technopole de Brest-Iroise, B.P. 70, 29280 Plouzané, France.
}

*: Corresponding author : Karine Lemarchand, email address : karine lemarchand@uqar.ca

\begin{abstract}
:
Rotifers (Brachionus plicatilis), commonly used at first feeding in commercial fish hatcheries, carry a large bacteria load. Because they are relatively poor in essential fatty acids, it is common practice to enrich them with fatty acids, including arachidonic acid (AA). This study aims to determine whether prey enrichment with AA may act as a prebiotic and modify the microbial community composition either in AA-enriched rotifer cultures or in larval-rearing water using winter flounder (Pseudopleuronectes americanus) as a larval fish model. AA enrichment modified the bacterial community composition in both the rotifer culture tanks and the larval-rearing tanks. We observed an increase in the number of cultivable bacteria on TCBS (thiosulfate-citrate-bile salts-sucrose) agar, used as a proxy for the abundance of Vibrio sp. The results suggest that AA may also play an indirect role in larval health.
\end{abstract}

Keywords: bacterial community ; rotifers ; arachidonic acid enrichment ; Vibrio sp. ; prebiotic

\section{Résumé:}

Les rotifères (Brachionus plicatilis), fréquemment utilisés comme première source alimentaire dans les piscicultures commerciales, portent une charge bactérienne importante. Parce qu'ils sont relativement pauvres en acides gras essentiels, il est de pratique courante de les enrichir en acides gras, notamment en acide arachidonique (AA). Cette étude vise à déterminer si l'enrichissement des proies à l'AA peut agir comme prébiotique et modifier la composition de la communauté microbienne non seulement dans les cultures de rotifères enrichies à l'AA, mais aussi dans l'eau d'élevage des larves, en utilisant la plie rouge (Pseudopleuronectes americanus) comme modèle de larves de poisson. L'enrichissement en AA a modifié la composition de la communauté microbienne tant dans les bassins de culture de rotifères que dans les bassins d'élevage des larves. Un accroissement du nombre de bactéries cultivables sur la gélose TCBS (thiosulfate - citrate - sels biliaires - sucrose), utilisée pour estimer l'abondance de Vibrio sp., a également été observé. Les résultats suggèrent que l'AA peut aussi jouer un rôle indirect dans la santé des larves. 
Mots-clés : communauté bactérienne ; rotifères ; enrichissement en acide arachidonique ; Vibrio sp. ; prébiotique

\section{Introduction}

The aquatic environment contains beneficial and neutral bacterial strains as well as a plethora of obligate and opportunistic bacterial pathogens that could represent a significant constraint on the commercial production of fish and shellfish. Over the last decade, the aquaculture industry has greatly increased its productivity and is now a major economic activity in many countries. The intensive rearing of marine larvae requires the addition of natural or artificial food sources to seawater. This activity could easily introduce numerous bacteria and, as a consequence, modify the microbial communities in the rearing environment or in organisms (Munro et al. 1994). Moreover, some production facilities use disinfection 
44 processes that may lead to the proliferation of opportunistic bacteria (Olafsen 2001), including 45 pathogens such as Vibrio (Schulze et al. 2006; Skjermo and Vadstein 1993). The gut microbial 46 communities of adult fish and fish resistance to infections will be greatly influenced by pioneer bacteria 47 in the diet and ambient water of developing larvae (Lubzens et al. 1985; Munro et al. 1994; Nicolas 48 1989; Ringø and Birkbeck 1999).

50 In commercial marine fish hatcheries, the rotifers Brachionus plicatilis and Brachionus rotundiformis

51 are commonly used at first feeding (Haché and Plante 2011). Without the proper enrichment, rotifers are

52 not suitable as live prey in intensive aquaculture since they do not contain all the essential nutrients

53 required to sustain larval growth and promote survival (Castell et al. 2003). Because rotifer cultures

54 carry a large bacterial load (Haché and Plante 2011; Skjermo and Vadstein 1993), they represent a

55 significant vector for bacterial transmission in larval cultures. A direct relationship has been 56 demonstrated between the bacterial flora found in the larvae and that in the live food (Munro et al. 57 1994). Commercial rotifer enrichments have also been shown to impact the bacterial load and the 58 bacterial community composition in live prey (Haché and Plante 2011; Høj et al. 2009) as well as in 59 larval fish cultures (Seychelles et al. 2011).

61 In a previous study, we demonstrated that arachidonic acid (AA) plays a crucial role in larval winter 62 flounder Pseudopleuronectes americanus development and that AA enrichment could modify bacterial 63 colonization of the intestinal lumen in this species (Seychelles et al. 2011). The present study focuses on 64 the effect of AA enrichment in rotifer cultures on the bacterial communities present in the hatchery 65 environment, especially in terms of total bacterial abundance, community composition, and the 
66 occurrence of specific pathogens such as Vibrio sp. in the rearing seawater of both rotifers and winter

67 flounder larvae fed with this live prey.

\section{Materials and methods}

\section{Rotifer culture}

72 Experiments were conducted at the UQAR-ISMER aquaculture facility (Pointe-au-Père, $48^{\circ} 27^{\prime} \mathrm{N} ; 68^{\circ}$

73 32' W, Quebec, Canada) from April to August 2006. Rotifers (Brachionus plicatilis) were cultured in six

74 replicate $18 \mathrm{~L}$ tanks at $20-25^{\circ} \mathrm{C}$ using aerated, filtered $(0.2 \mu \mathrm{m})$ seawater at a salinity of $27 \pm 1$. Rotifers

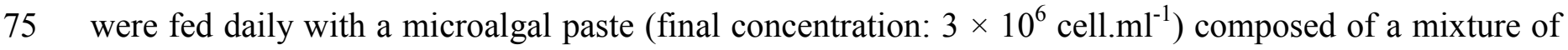

76 three non-viable microalgae (Nannochloropsis occulata, Pavlova lutheri, and Isochrysis galbana, $\mathrm{v} / \mathrm{v} / \mathrm{v}$ )

77 and a commercial enrichment (Culture Selco Plus, INVE Aquaculture, Belgium) as a complementary

78 protein source. Of the six replicates, three received an additional artificial supplement of AA (Sigma-

79 Aldrich \#10931-1G) at a ratio of $1 \mu \mathrm{g}$ for $10^{6}$ phytoplankton cells after dilution in ethanol (Seguineau et

80 al. 2005). The flagellates I. galbana and P. lutheri are good sources of docosahexaenoic DHA; P. lutheri

81 contains a high relative proportion of eicosapentaenoic acid (EPA); and the chlorophyceae N. occulata is

82 a good source of EPA and AA (Brown et al. 1997). Microalga culture conditions are described in

83 Seychelles et al. (2011). Rotifer culture tanks were sampled on days 4, 15, and 26 to determine the fatty

84 acid composition of rotifers and to describe the bacterial community present in rotifer-rearing seawater.

\section{Larval culture}

87 Detailed protocols for larval culture and sampling are given in Seychelles et al. (2011). Briefly, newly 88 hatched (day 0) winter flounder larvae were reared in three replicate $57 \mathrm{~L}$ cylindro-conical polyethylene 
89 tanks for each dietary treatment. Flounder larvae were fed rotifers from day 4 to 26 post hatching. After

90 day 26, the fish larvae needed larger-sized food and the experiment ended.

92 Rotifers were given in excess, and their density was adjusted three times a day to 5 rotifers. $\mathrm{ml}^{-1}$. Larval

93 tanks were supplied with filtered $(10 \mu \mathrm{m})$ seawater (salinity $27 \pm 1)$ and maintained at $10^{\circ} \mathrm{C}$ under a

94 12h:12h light:dark photoperiod; aeration provided upwelling water circulation. During the day, the water

95 intake was closed and the same microalgal paste used for rotifer enrichment was added to the larval

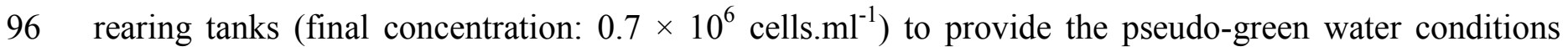

97 required for larval rearing. During night, water flow resumed and allowed for the complete renewal of

98 tank water. Flounder larvae were sampled just before lights-on and the first meal to ensure that stomachs

99 were empty. Sampling was done at mouth opening (day 4) and on days 15 and 26 for dry weight

100 determination. At the end of the rotifer-feeding period (day 26), 10 larvae per larval tank (total of 30 in

101 the AA-enriched treatment and 20 in the control treatment) were fixed with $10 \%$ formaldehyde ( $\geq 24 \mathrm{~h}$

102 at ambient temperature) for light microscopy observations. Fixed larvae were dehydrated in an

103 ascending series of ethanol solutions and embedded in methacrylate resin for histological observation, as

104 described in Seychelles et al. (2011). The same sampling periods were used for bacterial analyses in

105 larval-rearing seawater.

106

107 Rotifer fatty acid composition

108 At days 4, 15, and 26, two samples of 20000 rotifers were collected from each tank and pre-rinsed with 109 filtered seawater $(0.2 \mu \mathrm{m})$ on a $50 \mu \mathrm{m}$ net before being filtered onto pre-combusted $\left(450^{\circ} \mathrm{C}\right) \mathrm{GF} / \mathrm{C}$ filters 110 (25 mm) for fatty acid analysis. As described in Seychelles et al. (2011), fatty acid profiles were 111 determined on a Varian CP3900 gas chromatograph (Varian, Canada) equipped with a ZB-wax fused 
112 silica capillary column $(20 \mathrm{~m} \times 0.18 \mathrm{~mm}$ internal diameter $\times 0.18 \mu \mathrm{m}$ film thickness; Supelco $)$ after 113 extraction following Folch et al. (1957); fatty acid methyl esters were obtained by acid catalyzed 114 transesterification with $2 \%(\mathrm{v} / \mathrm{v}) \mathrm{H}_{2} \mathrm{SO}_{4}$ in methanol at $100^{\circ} \mathrm{C}$.

116 Total bacteria abundance

117 Total bacteria abundance was determined in the rotifer-rearing seawater and in the larval-rearing 118 seawater on days 4,15 , and 26 . All samplings were done early in the morning, before the addition of 119 enrichment to the rotifer tanks or before the addition of green water and food to the larval tanks. 120 Additional samples were taken of seawater before it entered the rearing tanks ("source seawater") at the 121 beginning of the experiment (day 0 ) and on days 4,15 , and 26 to determine the natural bacterial 122 abundance. Each sampling included two $4 \mathrm{ml}$ aliquots of seawater fixed in $2 \%$ formaldehyde (final 123 concentration; $\mathrm{pH}$ 7). Samples were frozen at $-80^{\circ} \mathrm{C}$ until further analyses. Total free bacteria (TB) were 124 enumerated using an EPICS ALTRA ${ }^{\mathrm{TM}}$ cell sorting flow cytometer (Beckman-Coulter Inc., Mississauga, 125 ON, Canada) equipped with a laser emitting at $488 \mathrm{~nm}$. Fluorescent beads (Fluoresbrite YG $1 \mu \mathrm{m}$ 126 microspheres, Polysciences ${ }^{\mathrm{TM}}$ ) were systematically added to each sample as an internal standard to 127 normalize cell fluorescence emission and light scatter values. For the analysis of bacterial abundance, 128 frozen samples were thawed and two subsamples of $1 \mathrm{ml}$ were half-diluted in TE 10X buffer $(100 \mathrm{mM}$ 129 Tris- $\mathrm{HCl}, 10 \mathrm{mM}$ EDTA, $\mathrm{pH}$ 8). A $1 \mathrm{ml}$ volume of the resulting diluted sample was stained with $0.25 \mu \mathrm{l}$ 130 of SYBR Green I nucleic acid gel stain ( $\mathrm{Ci}=10,000 \mathrm{X}$, Invitrogen, Inc.), incubated for $10 \mathrm{~min}$ at room 131 temperature in the dark, and analyzed for 180s. To calculate bacterial cell abundances, the volume 132 analyzed was calculated by weighing samples before and after each run. This volume was corrected for 133 a dead volume of $50 \mu 1$ (the water volume taken from the sample tube but not counted when data 134 acquisition is stopped). 
136 TB were detected in a plot of green fluorescence recorded at $530 \pm 30 \mathrm{~nm}$ (FL1) versus side angle light 137 scatter (SSC). Bacteria with high, very high, and low nucleic acid content (HNA, VHNA, and LNA 138 subgroups, respectively) were discriminated by gating the FL1-versus-SSC plot, and the abundances of 139 all subgroups were determined (Lebaron et al. 2001). For the purpose of this study, TB abundance was 140 used to describe the bacterial community distribution, and \%HNA (the ratio of HNA cells to TB) was 141 used to describe the physiological structure of the bacterial community, as has been suggested by 142 different studies (Gasol and del Giorgio 2000; Gasol et al. 1999; Lebaron et al. 2001)

\section{Bacteria cultivable on TCBS}

145 Bacteria forming colonies (colony forming units, CFU) were enumerated in triplicate from day 4 to 26 146 after 24 to $48 \mathrm{~h}$ of incubation at room temperature in the dark on TCBS agar (thiosulfate-citrate-bile 147 salts-sucrose; Merck KgaA, Germany). Cultures on TCBS agar were used to estimate the number of 148 Vibrio sp. in the samples (Buller 2004). Only colonies with the characteristics of Vibrio sp. (good 149 growth, yellow colonies with halo) were counted, but because no definite identification was made of the 150 colonies, the expression "CFU on TCBS" will be used to refer these counts.

\section{Bacteria colonizing larvae}

153 Fixed larvae were dehydrated in an ascending series of ethanol solutions and embedded in methacrylate 154 resin. Tissues were sectioned ( $3 \mu \mathrm{m}$ thickness) with a Supercut Reichert-Jung model 2050 (Cambridge 155 Instruments GMbH, Germany). Sections were mounted onto glass slides, stained with the Gram Staining 156 kit (Sigma \#77730), and photographed at 1000X (Olympus BX41, Japan). The occurrence of bacteria 157 was determined and quantified in gut lumen, gills, and skin. Bacterial density was randomly calculated 
158 within the intestinal lumen (number of bacteria. $\mathrm{mm}^{-2}$ ), and the ratio "area occupied by bacteria/total 159 tissue area" was calculated on three histological gill and fin sections for each larva using the Image Pro 160 Plus software (Media Cybernetics, Canada).

\section{Bacterial community characterization}

163 Bacterial community composition was analyzed from larva- and rotifer-rearing seawater and from 164 source seawater. Samples $(200 \mathrm{ml})$ were filtered on polycarbonate membranes $(0.2 \mu \mathrm{m}$ pore size, $25 \mathrm{~mm}$ 165 diameter); the filters were then cut and transferred to sterile $1.5 \mathrm{ml}$ tubes containing $840 \mu 1$ of lysis 166 buffer (40 mM EDTA, $50 \mathrm{mM}$ Tris, $\mathrm{pH} \mathrm{8,} 0.75 \mathrm{M}$ sucrose) and $50 \mu 1$ of lysozyme $\left(20 \mathrm{mg}^{-\mathrm{ml}^{-1}}\right)$, and 167 incubated for $45 \mathrm{~min}$ at $37^{\circ} \mathrm{C}$ (Ghiglione et al. 2005). Next, $100 \mu \mathrm{l}$ of sodium dodecyl sulfate solution $168(10 \%)$ and $10 \mu \mathrm{l}$ of proteinase $\mathrm{K}\left(20 \mathrm{mg} \cdot \mathrm{ml}^{-1}\right)$ were added to each sample and incubated at $55^{\circ} \mathrm{C}$ for 60 169 min. Total DNA extraction was then performed using a classic phenol-chloroform-isoamyl alcohol $170(25 / 24 / 1)$ protocol. PCR amplification of the 16S rDNA gene was then performed using a Mastercycler 171 epS (Eppendorf) thermal cycler following the method proposed by Schäfer and Muyzer (2001). Three 172 PCR amplifications were performed on each DNA sample to overcome the effect of PCR biases 173 (Perreault et al. 2007). Amplicons were then purified with MinElute (QIAGEN) columns according to 174 the manufacturer's instructions and stored at $-20^{\circ} \mathrm{C}$ prior to analysis by denaturing gradient gel 175 electrophoresis (DGGE). DGGE was performed using a DGGE-4001-Rev-B (C.B.S. Scientific 176 Company, CA, USA) system according to Schäfer and Muyzer (2001). Gels were stained with a half177 diluted solution of SYBR Green I (10,000X, Molecular Probes, Oregon) for $1 \mathrm{~h}$ according to the 178 manufacturer's instructions. Gels were photographed under UV light, and DGGE profiles were analyzed 179 using an AlphaImager HP (Alpha-Innotech). The number of bands, corresponding to different 180 operational taxonomic units (OTU), was determined, and the comparison between DGGE fingerprints 
181 was performed using the Phoretix 1D Pro software (TotalLab Limited, Nonlinear Dynamics, Newcastle 182 upon Tyne, UK) on the basis of a similarity matrix using Jaccard's index (Bourne et al. 2006; Clarke 183 1993).

185 Statistical analyses

186 All statistical analyses were done using STATISTICA software version 6.0 (Statsoft, USA) with $\alpha=$ 187 0.05. Data normality was examined using the Kolmogorov-Smirnov test and homoscedasticity tested 188 with the Brown-Forsythe test (Zar 1999). Differences between treatments were tested using a one-way 189 ANOVA (rotifer diet, D) or a two-way repeated ANOVA (rotifer diet and sampling time, T). For 190 subsequent multiple comparisons, Tukey tests or Tukey tests for unequal $\mathrm{n}$ were performed when 191 appropriate. Data related to CFU counts on TCBS in source seawater were square-root transformed. The 192 Games \& Howell test was used when heteroscedasticity was observed.

194 Results

196 Rotifer enrichment

197 The level of AA in enriched rotifers was three-fold higher than that in control rotifers. Other essential 198 fatty acids (EPA and DHA) and total fatty acids were similar for the two diets (Table 1).

\section{Bacterial communities}

201 In source seawater, TB abundance was similar from day 0 to 15 and was 1.3 -fold higher on day 26 (T: p $202<0.001, \mathrm{~F}=11.12, \mathrm{df}=3)($ Table 2$)$. TB abundance was 10,000-fold higher in rotifer cultures than in 203 larval-rearing seawater on days 4 and 15 and 1,000-fold higher on day 26. TB abundance in larval tanks 
204 followed the same pattern as that observed in source seawater, with similar values from day 4 to 15 and 205 a significant increase (1.2-fold higher) on day $26(\mathrm{~T}: \mathrm{p}<0.001, \mathrm{~F}=9.17, \mathrm{df}=3)($ Table 2$)$. Conversely, 206 TB abundance in rotifer tanks reached a higher level and dropped significantly on day 26 (T: p $<0.001$, $207 \mathrm{~F}=9.32, \mathrm{df}=2)$ in the two treatments $(\mathrm{D}, \mathrm{D} \times \mathrm{T}: \mathrm{p}>0.05)($ Table 3$)$.

209 Bacterial communities in rotifer-rearing seawater and in larval-rearing seawater had different 210 proportions of HNA, LNA, and VHNA subpopulations (Fig. 1-2). HNA and LNA bacterial 211 subpopulations were observed in the rearing seawater of all tanks during the experiment (Fig. 1-2), but 212 the percentage of HNA cells was lower in rotifer-rearing seawater than in larval-rearing seawater 213 (Tables 2-3). On day 26, the VHNA subpopulation was four-fold higher in the control larval tanks than 214 in the AA-enriched tanks (Table 2). No VHNA subpopulation was detected in the source seawater.

216 DGGE fingerprint patterns indicated marked differences in the bacterial community composition in 217 larval- and rotifer-rearing seawater. The number of OTUs in source seawater ranged between 19 on day 2184 and 12 on day 26. OTUs were more numerous in the larval-rearing seawater, with 25 on day 4 and 16 219 on day 26, independent of the diet. In AA-enriched rotifer rearing seawater, only 9 OTUs were observed 220 on day 4 and 10 on day 26. In the rearing seawater of control rotifers (no AA enrichment), the number of 221 OTUs was slightly higher, with 12 on day 4 and 13 on day 26.

223 The cluster analysis of DGGE fingerprints (Fig. 3) indicated that control and AA-enriched rotifer224 rearing seawater samples were clustered according to the AA-enrichment procedure and that bacterial 225 community composition in the rotifer-rearing seawater was poorly correlated with the bacterial 226 community composition in the corresponding larval-rearing seawater, as indicated by the relatively large 
227 distance (> 0.75). The bacterial community composition was similar in the source seawater and in larval 228 tanks receiving non-enriched rotifers throughout the experiment. On day 4 , the bacterial community 229 composition was similar in larval-rearing seawater for the two different larval diets (control and AA230 enriched), and the bacterial community composition in the larval tanks receiving the AA-enriched diet 231 was very similar to that of the source seawater (Jaccard's distance 0.31). On day 26, the distance 232 increased (0.68) between AA-enriched and control samples, whereas control and seawater source 233 samples had a similar bacterial community composition (0.44).

235 CFU counts on TCBS in source seawater were low and similar from day 0 to $15\left(0.6 \pm 0.7\right.$ CFU.ml $\left.{ }^{-1}\right)$ 236 but slightly higher on day $26\left(2.2 \pm 0.3 \mathrm{CFU} \cdot \mathrm{ml}^{-1}\right)(\mathrm{D}: \mathrm{p}<0.001, \mathrm{~F}=20.35, \mathrm{df}=3)$. A similar pattern 237 was observed in AA-enriched larval tanks, where CFU counts peaked on day 26 (D $\times \mathrm{T}: \mathrm{p}<0.001, \mathrm{~F}=$ $238943.77, \mathrm{df}=3$ ) at a level 35 -fold higher than observed in source seawater. CFU counts in control larval 239 tanks slightly increased on day 26 and was 5 -fold higher than the count observed in source seawater on 240 days 0 and 4 (Fig. 4A). CFU counts were 3- to 14-fold higher in rotifer cultures than the highest count 241 observed in larval tanks. In AA-enriched rotifer tanks, the count peaked on day 15 and was more than 242 twice as high $(\mathrm{D} \times \mathrm{T}: \mathrm{p}<0.001, \mathrm{~F}=24.44, \mathrm{df}=2)$ on days 15 and 26 compared to control rotifer tanks 243 (Fig. 4B).

245 Histological observations in larval intestinal lumen, gills, and skin revealed no significant difference in 246 bacterial colonization between larval groups at the end of the experiment (day 26). Bacterial densities in 247 control larvae and larvae fed AA-enriched rotifers were respectively $2.5 \times 10^{3} \pm 2.3 \times 10^{3}$ and $2482.3 \times 10^{3} \pm 2.5 \times 10^{3}$ bacteria $\mathrm{mm}^{-2}$ in intestinal lumen, $28.5 \pm 35.8 \%$ and $34.5 \pm 48.6 \%$ of the gill area, 249 and $16.3 \pm 16.3 \%$ and $11.7 \pm 8.5 \%$ of the fin area. Fish larvae from both treatments exhibited similar 
250 total lengths $(5.36 \pm 0.55 \mathrm{~mm})$, widths $(1.07 \pm 0.15 \mathrm{~mm})$, and dry weights $\left(0.083 \pm 0.035 \mathrm{mg} \cdot\right.$ larva $\left.^{-1}\right)$ at 251 the end of the experiment.

253 Discussion

The AA enrichment process did not affect TB abundance in either rotifer or larval tanks during the 26 days of the experiment. Bacterial concentrations in rotifer tanks were four orders of magnitude greater than in larval tanks, where TB abundances $\left(\sim 10^{5}\right.$ cells. $\left.\mathrm{ml}^{-1}\right)$ corresponded to concentrations generally reported in seawater from the St. Lawrence Estuary. In this experiment, TB abundances were expressed as total counts and not as CFU counts, but considering that a maximum of $10 \%$ of total marine bacteria are cultivable, our results are similar to those reported by Skerjmo and Valdstein (1993) and Haché and 261 Plante (2011) in their commercially enriched rotifer cultures. The differences observed between 262 seawater in larval tanks and rotifer culture tanks could be attributed to the dissolved organic matter 263 (DOM) supply (Nagata 2000) associated with the grazing of algae by rotifers, which may enhance 264 bacterial degradation and as a consequence promote bacterial multiplication. This is confirmed by the 265 higher percentage of VHNA bacteria cells in rotifer cultures than in source seawater. VHNA cells are 266 identified by their high fluorescence and their high amount of nucleic acids. These results indicate that 267 around $50 \%$ of bacterial cells are highly productive in these cultures. In larval fish cultures, VHNA 268 bacteria cells were only detected after day $15(\sim 10 \%$ of total cells) while they were observed in rotifer 269 cultures throughout the experiment. Nishimura et al. (2005) found a negative correlation between $270 \%$ VHNA and chlorophyll $a$ concentration. The late appearance of VHNA bacteria in larval tanks could 271 be explained by the daily water renewal, which reduced the availability of DOM at the beginning of the 272 larval rearing. Since VHNA cells were not observed in source seawater, these cells were probably 
273 transferred from rotifer to larval cultures and actively contributed to changes in the larval tank 274 microflora. Nevertheless, considering only TB abundances and community structure, AA enrichment 275 produced no significant modifications of the bacterial community in rotifer- or larval-rearing seawater.

277 In contrast, CFU counts on TCBS agar sharply increased in both rotifer and larval-rearing seawater with 278 AA enrichment. The TCBS medium is used to identify bacteria of the genus Vibrio, which are 279 ubiquitous in the marine environment and potentially important pathogens of marine and brackish-water 280 fish (Reed and Francis-Floyd 1996). Since only low concentrations of these bacteria were observed in 281 the source seawater during the experiment, the increase in CFU counts on the TCBS medium in our 282 cultures was probably due to our experimental culture conditions, which included the addition of live 283 food in the tanks. Although the microbial communities associated with live food can be very different 284 between marine fish hatcheries (Skjermo and Vadstein 1993), most bacteria identified in rotifer cultures 285 have been from the Vibrionaceae family, which includes two important genera of fish pathogens, 286 Aeromonas and Vibrio. Other notable fish pathogens identified were Moraxella and Flavobacterium 287 (Rombaut et al. 2001; Verdonck et al. 1994). Because larvae were not uniformly distributed in rearing 288 tanks (patchy distribution) and the tiny dead larvae decomposed very rapidly in sea water, we were not 289 able to compare mortality rates in the different larval treatments and to correlate them with the increase 290 in bacteria cultivable on TCBS agar. However, the increase in bacteria cultivable on TCBS agar did not 291 alter larval development: both groups (AA-enriched and non- enriched food sources) had similar growth 292 (used as proxy for larval health) and similar bacterial colonization in their tissues, despite strong inter293 individual variations. This has also been observed in the intestines of goldfish Carassius auratus (Asfie 294 et al. 2003; Sugita et al. 1988), carp Cyprinus carpio, and tilapia Oreochromis mossambicus (Asfie et al. 295 2003). Thus though AA enrichment may enhance the development of bacteria that are cultivable on 
296 TCBS agar, these bacteria did not seem pathogenic for winter flounder larvae under our culture 297 conditions.

299 The cluster analysis of the DGGE fingerprint patterns of the larval rearing water over 26 days confirms 300 that winter flounder larvae are exposed to different bacteria before feeding on day 4 and after the onset 301 of exogenous feeding on days 15 and 26. Since bacterial populations representing at least $1 \%$ of the total 302 community can be detected by PCR-DGGE (Muyzer and Smalla 1998), this method is a good tool for 303 characterizing bacterial populations present during early life stages of fish larvae in hatcheries 304 (Brunvold et al. 2007). Our results demonstrated that the bacterial community composition developed 305 differently in rotifer and larval-rearing seawater through the experiment. Furthermore, we observed a 306 change in the bacterial community composition between the beginning and the end of the experiment 307 (day 4 and 26). Brunvold et al. (2007) demonstrated a similar change in the bacterial community 308 associated with hatchery cod larvae, corresponding to the onset of exogenous feeding and a relatively 309 stable bacterial community during larval feeding on rotifers. In the present experiment, the number of 310 OTUs decreased in all larval treatments, with a reduction of 9 OTUs from day 4 to day 16 without any 311 effect related to the diet. Since a reduction of 7 OTUs was observed in the source seawater, the decrease 312 in the larval-rearing seawater may be partly explained by the source seawater. There were fewer OTUs 313 in rotifer seawater samples than in source seawater: only 9 and 12 OTUs were observed on day 4 in AA314 enriched and control rotifer tanks, respectively. While the number of OTUs did not change in rotifer 315 tanks, DGGE fingerprints indicate a modification of the community composition: only 6 and 7 OTUs 316 were common to the day 4 and day 16 samples in AA-enriched and control rotifer tanks, respectively 317 (data not shown). At the end of the experiment, only 6 OTUs were common to AA-enriched and control 318 rotifer tanks out of the 23 OTUs that were present. Thus even though slight modifications were observed 
319 in the larval rearing seawater of larvae fed enriched rotifers, the AA enrichment seems to interact with 320 the bacterial community in rotifer tanks. The DGGE fingerprint cluster analysis revealed a marked

321 distance between water samples from rotifer and larval tanks, which suggests that even if some bacteria 322 were introduced with rotifers, these bacteria did not become dominant in the bacterial community of the 323 larval tanks.

325 The proliferation of bacteria in intensive aquaculture systems may be responsible for poor growth and 326 mass mortality of marine fish larvae. Essential fatty acids provided in the diet could protect larvae by 327 modulating the immune response via AA and EPA. The antibacterial effect of a given fatty acid is 328 influenced by its structure and shape, with unsaturated fatty acids tending to have greater potency at low 329 concentrations (Kabara 1978; Kanai and Kondo 1979; Nieman 1954) than saturated fatty acids with the 330 same carbon chain length (Desbois and Smith 2010; Knapp and Melly 1986; Kodicek 1949). For 331 example, AA is more toxic for gram-positive bacteria than for gram-negative species, such as bacteria of 332 the genus Vibrio. The gram-negative species sensitive to AA have a more permeable outer membrane 333 than other negative species (Knapp and Melly 1986). In our study, AA enrichment may have contributed 334 to the development of AA-resistant bacteria species cultivable on TCBS, especially in rotifer cultures. 335 Such bacterial resistance or growth inhibition has been observed in vitro on Escherichia coli and 336 Pseudomonas aeruginosa strains challenged with gamma-linoleic acid, DHA, and AA (Giamarellos337 Bourboulis et al. 1994, 1995). The gut microflora of adult fish and the fish's resistance to infections are 338 greatly influenced by the pioneer bacteria in the diet and in the ambient rearing water of the developing 339 larvae. However, we observed no difference in larval development with or without AA enrichment of 340 the rotifers after 26 days of experimentation, suggesting no positive or negative effects for larvae. 
342 In conclusion, we previously demonstrated that AA plays a crucial role in winter flounder larval 343 development and that AA enrichment could modify bacterial colonization of the intestinal lumen in this 344 species (Seychelles et al. 2011). The present study demonstrates that AA also modifies the nature of the 345 bacterial communities present both in prey (rotifers) and in larval-rearing water. The next step would be 346 to precisely identify which bacteria are positively and negatively affected by the addition of AA and to 347 test if they can directly alter larval health or if they could act as prebiotics.

349 Acknowledgments

350 The authors would like to thank Institut de recherche sur les zones côtières (IRZC) personnel Claude J. 351 Pelletier for the chromatographic analysis and Josée Duguay for technical help. We are grateful to 352 Erwann Fraboulet, Marie Parenteau, Francis Jacques, and Karine Dumont. This project was funded by 353 SODIM (Société de développement de l'Industrie Maricole inc.), RAQ (Réseau Aquaculture Québec), 354 and by the Programme de coopération Québec Nouveau-Brunswick. 


\section{References}

359 Asfie, M., Yoshijima, T., and Sugita, H. 2003. Characterization of the goldfish fecal microflora by the 360 fluorescent in situ hybridization method. Fisheries Science 69: 21-26. doi:10.1046/j.1444$361 \quad 2906.2003 .00583 . x$.

362 Bourne, D.G., Høj, L., Webster, N.S., Swan, J., and Hall, M.R. 2006. Biofilm development within a 363 larval rearing tank of the tropical rock lobster, Panulirus ornatus. Aquaculture 260: 27-38.

364 Brown, M.R., Jeffrey, S.W., Volkman, J.K., and Dunstan, G.A. 1997. Nutritional properties of 365 microalgae for mariculture. Aquaculture 151: 315-331. doi: 10.1016/S0044-8486(96)01501-3.

366 Brunvold, L., Sandaa, R.-A., Mikkelsen, H., Welde, E., Bleie, H., and Bergh, Ø. 2007. Characterisation 367 of bacterial communities associated with early stages of intensively reared cod (Gadus morhua) using 368 Denaturing Gradient Gel Electrophoresis (DGGE). Aquaculture 272: 319-327. 369 doi:10.1016/j.aquaculture.2007.08.053.

370 Buller, N.B. 2004. Bacteria from fish and other aquatic animals - a pratical identification manual. CABI, 371 Oxfordshire, UK.

372 Castell, J., Blair, T., Neil, S., Howes, K., Mercer, S., Reid, J., Young-Lai, W., Gullison, B., Dhert, P. and 373 Sorgeloos, P. 2003. The effect of different HUFA enrichment emulsions on the nutritional value of 374 rotifers (Brachionus plicatilis) fed to larval haddock (Melanogrammus aeglefinus). Aquaculture 375 International 11: 109-117. doi:10.1023/A:1024154106656.

376 Clarke, K.R. 1993. Non-parametric analyses of changes in community structure. Australian Journal of 377 Ecology 18: 117-143.

378 Desbois, A.P., and Smith, V.J. 2010. Antimicrobial free fatty acids: activities, mechanisms of action and 379 biotechnological potential. Applied Microbiology and Biotechnology 85: 1629-1642. 
380 Folch, J., Lees, M. \& Sloane-Stanley, G.H. 1957. A simple method for the isolation and purification of 381 total lipids from animal tissues. Journal of Biological Chemistry 226: 497-509.

382 Gasol, J.M., and del Giorgio, P.A. 2000. Using flow cytometry for counting natural planktonic bacteria 383 and understanding the structure of planktonic bacterial communities. Scientia Marina 64: 197-224.

384 Gasol, J.M., Zweifel, U.L., Peters, F., and Fuhrman, J.A. 1999. Significance of size and nucleic acid 385 content heterogeneity as measured by flow cytometry in natural planktonic bacteria. Applied and 386 Environmental Microbiology 65: 4475-4483.

387 Ghiglione, J.-F., Larcher, M., and Lebaron, P. 2005. Spatial and temporal scales of variation in 388 bacterioplankton community structure in the NW Mediterranean Sea. Aquatic Microbial Ecology 40: $389 \quad 229-240$.

390 Giamarellos-Bourboulis, E.J., Grecka, P., Dionyssiou-Asteriou, A., and Giamarellou, H. 1995. In vitro 391 inhibitory activity of gamma-linolenic acid on Escherichia coli strains and its influence on their 392 susceptibilities to various antimicrobial agents. Journal of Antimicrobial Chemotherapy 36: 327-334.

393 Giamarellos-Bourboulis, E.J., Grecka, P., Dionyssiou-Asteriou, A., Grammatikou, M., and Giamarellou, 394 H. 1994. Do Escherichia coli susceptibilities to various antibiotics decrease in the presence of 395 polyunsaturated fatty acids? - a preliminary report. Journal of Chemotherapy 6: 39-43.

396 Haché, R., and Plante, S. 2011. The relationship between enrichment, fatty acid profiles and bacterial 397 load in cultured rotifers (Brachionus plicatilis L-strain) and Artemia (Artemia salina strain Franciscana). 398 Aquaculture 311: 201-208.

399 Høj, L., Bourne, D.G., and Hall, M.R. 2009. Localization, abundance and community structure of 400 bacteria associated with Artemia: effects of nauplii enrichment and antimicrobial treatment. Aquaculture 401 International 293: 278-285. doi:10.1016/j.aquaculture.2009.04.024. 
402 Kabara, J.J. 1978. Fatty acids and derivatives as antimicrobial agents - a review. In The pharmacological 403 effect of lipids. Edited by J. J. Kabara. The American Oil Chemists' Society, Champaign, IL, USA. pp. $404 \quad 1-14$

405 Kanai, K., and Kondo, E. 1979. Antibacterial and cytotoxic aspects of long-chain fatty acids as cell 406 surface events: selected topics. Japanese Journal of Medical Science Biology 32: 135-174.

407 Knapp, H.R., and Melly, M.A. 1986. Bactericidal effects of polyunsaturated fatty acids. The Journal of 408 Infectious Diseases 154: 84-94.

409 Kodicek, E. 1949. The effect of unsaturated fatty acids on gram-positive bacteria. Society for 410 Experimental Biology Symposia 3: 218-231.

411 Lebaron, P., Servais, P., Agogué, H., Courties, C., and Joux, F. 2001. Does the high nucleic acid content 412 of individual bacterial cells allow us to discriminate between active cells and inactive cells in aquatic 413 systems? Applied and Environmental Microbiology 67: 1775-1782.

414 Lubzens, E., Marko, A., and Tietz, A. 1985. De novo synthesis of fatty acids in the rotifer Brachionus 415 plicatilis. Aquaculture 47: 27-37.

416 Munro, P.D., Barbour, A., and Birkbeck, T.H. 1994. Comparison of the gut bacterial-flora of start417 feeding larval turbot reared under different conditions. Journal of Applied Bacteriology 77: 560-566.

418 Muyzer, G., and Smalla, K. 1998. Application of denaturing gradient gel electrophoresis (DGGE) and 419 temperature gradient gel electrophoresis (TGGE) in microbial ecology. Antonie van Leeuwenhoek 73: 420 127-141. doi:10.1023/a:1000669317571.

421 Nagata, T. 2000. Production mechanisms of dissolved organic matter. In Microbial ecology of the 422 oceans. Edited by D. L. Kirchman. John Wiley \& Sons, New York, N.Y. pp. 121-152.

423 Nicolas, J. 1989. Bacterial flora associated with a trophic chain consisting of microalgae, rotifers and 424 turbot larvae: Influence of bacteria on larval survival. Aquaculture 83: 237-248. 
425 Nieman, C. 1954. Influence of trace amounts of fatty acids on the growth of microorganisms. 426 Bacteriology Reviews 18: 147-163.

427 Nishimura, Y., Kim, C., and Nagata, T. 2005. Vertical and seasonal variations of bacterioplankton 428 subgroups with different nucleic acid contents: possible regulation by phosphorus. Applied and 429 Environmental Microbiology 71: 5828-5836. doi:10.1128/aem.71.10.5828-5836.2005.

430 Olafsen, J.A. 2001. Interactions between fish larvae and bacteria in marine aquaculture. Aquaculture $431 \quad 200: 223-247$.

432 Perreault, J., Perreault, J.P., and Boire, G. 2007. The Ro associated Y RNAs in metazoans: Evolution 433 and diversification. Molecular Biology and Evolution 24: 1678-1689.

434 Reed, P.A., and Francis-Floyd, R. 1996. Vibrio infections of fish. Department of Fisheries and Aquatic 435 Sciences, Institute of Food and Agricultural Sciences, University of Florida.

436 Ringø, E., and Birkbeck, T.H. 1999. Intestinal microflora of fish larvae and fry: A review. Aquaculture 437 Research 30: 73-93.

438 Rombaut, G., Suantika, G., Boon, N., Maertens, S., Dhert, P., Top, E., Sorgeloos, P., and Verstraete, W. 439 2001. Monitoring of the evolving diversity of the microbial community present in rotifer cultures. 440 Aquaculture 198: 237-252. doi:10.1016/s0044-8486(01)00594-4.

441 Schäfer, H., and Muyzer, G. 2001. Denaturing gradient gel electrophoresis in marine microbial ecology. 442 Methods in Microbiology 30: 425-468.

443 Schulze, A.D., Alabi, A.O., Tattersall-Sheldrake, A.R., and Miller, K.M. 2006. Bacterial diversity in a 444 marine hatchery: Balance between pathogenic and potentially probiotic bacterial strains. Aquaculture 445 256: $50-73$. 
446 Seguineau, C., Soudant, P., Moal J., Delaporte A., Miner, P., Quéré, C. and Samain, J.-F. 2005.

447 Techniques for delivery of arachidonic acid to Pacific oyster, Crassostrea gigas, spat. Lipids 40: 31-939. 448 doi: 10.1007/s11745-005-1454-5.

449 Seychelles, L.H., Audet, C., Tremblay, R., Lemarchand, K., and Pernet, F. 2011. Bacterial colonization 450 of winter flounder Pseudopleuronectes americanus fed live feed enriched with three different 451 commercial diets. Aquaculture Nutrition 17: e196-e206.

452 Skjermo, J., and Vadstein, O. 1993. Characterization of the bacterial flora of mass cultivated Brachionus 453 plicatilis. Hydrobiologia 255: 185-191.

454 Sugita, H., Tsunohara, M., Ohkoshi, T., and Deguchi, Y. 1988. The establishment of an intestinal 455 microflora in developing goldfish (Carassius auratus) of culture ponds. Microbial Ecology 15: 333-344. 456 doi:10.1007/bf02012646.

457 Verdonck, L., Swings, J., and Kersters, K. 1994. Variability of the microbial environment of rotifer 458 Brachionus plicatilis and Artemia production systems. Journal of the World Aquaculture Society 25: 5545959.

460 Zar, J.H. 1999. Biostatistical analysis. Prentice Hall, New Jersey. 461 462 
Table 1 Selected fatty acid composition (mean \pm SD) of rotifers fed control and AA-enriched diets. Asterisks indicate a significant difference between the two diets. AA: Arachidonic acid; DHA: docosahexaenoic acid; EPA: eicosapentaenoic acid; SFA: saturated fatty acids; MUFA: monounsaturated fatty acids; PUFA: polyunsaturated fatty acids.

\begin{tabular}{rccc}
\hline & $\begin{array}{c}\text { Control } \\
\text { rotifers }\end{array}$ & $\begin{array}{c}\text { AA-enriched } \\
\text { rotifers }\end{array}$ & Summary of ANOVA results \\
\hline $\begin{array}{l}\text { Fatty acid proportions } \\
\text { (\% TFA) and ratio }\end{array}$ & & & \\
& & & DA \\
EPA & $0.9 \pm 0.2$ & $3.0 \pm 0.9^{*}$ & D: $0.001 ; \mathrm{D} \times \mathrm{T}: p>0.05$ \\
DHA & $2.7 \pm 0.5$ & $3.7 \pm 0.9$ & All NS \\
SFA & $21.6 \pm 0.9$ & $22.3 \pm 0.6$ & T: $p<0.01 ; \mathrm{D} \times \mathrm{T}: p>0.05$ \\
MUFA & $55.5 \pm 2.7^{*}$ & $53.2 \pm 3.5$ & D, T: $p<0.01 ; \mathrm{D} \times \mathrm{T}: p>0.05$ \\
PUFA & $22.9 \pm 2.4$ & $24.5 \pm 2.8^{*}$ & D, T: $p<0.01 ; \mathrm{D} \times \mathrm{T}: p>0.05$ \\
DHA:EPA & $0.7 \pm 0.1$ & $0.8 \pm 0.2$ & All NS $p>0.05$ \\
Total fatty acids $\left(\mathrm{mg} \mathrm{g}^{-1}\right.$ ) & $19.5 \pm 6.8$ & $25.8 \pm 8.9$ & All NS \\
\hline
\end{tabular}

D: diet; T: sampling time; $\mathrm{D} \times \mathrm{T}$ : interaction between $\mathrm{D}$ and T; NS: not significant. 
Table 2 Concentrations of total free bacteria (TB) and bacteria with high (HNA) and very high (VHNA) nucleic acid contents in fish culture water and source seawater (sampled prior to use in the larval tanks).

\begin{tabular}{|c|c|c|c|c|c|c|c|c|c|}
\hline \multirow[b]{2}{*}{ Sample } & \multicolumn{3}{|c|}{$\begin{array}{c}\text { TB } \\
\left(\times 10^{5} \text { bacteria.ml }^{-1}\right)\end{array}$} & \multicolumn{3}{|c|}{$\begin{array}{c}\text { HNA } \\
\left(\times 10^{5} \text { bacteria.ml }^{-1}\right) \\
(\% \text { HNA }) \\
\end{array}$} & \multicolumn{3}{|c|}{$\begin{array}{c}\text { VHNA } \\
\left(\times 10^{4} \text { bacteria.ml }^{-1}\right) \\
(\% \text { VHNA }) \\
\end{array}$} \\
\hline & Day 4 & Day 15 & Day 26 & Day 4 & Day 15 & Day 26 & Day 4 & Day 15 & Day 26 \\
\hline SW & $2.70 \pm 0.26$ & $2.84 \pm 0.26$ & $3.63 \pm 0.58$ & $\begin{array}{c}2.10 \pm 0.22 \\
(77.52)\end{array}$ & $\begin{array}{c}2.15 \pm 0.18 \\
(75.61)\end{array}$ & $\begin{array}{l}2.91 \pm 0.40 \\
(80.27)\end{array}$ & ND & ND & ND \\
\hline CLT & $2.58 \pm 0.15$ & $2.94 \pm 0.29$ & $3.42 \pm 0.07$ & $\begin{array}{c}2.28 \pm 0.12 \\
(78.53)\end{array}$ & $\begin{array}{c}2.20 \pm 0.38 \\
(74.64)\end{array}$ & $\begin{array}{c}2.65 \pm 0.19 \\
(72.21)\end{array}$ & ND & $\begin{array}{c}2.47 \pm 0.01 \\
(8.38)\end{array}$ & $\begin{array}{c}5.71 \pm 0.20 \\
(15.53)\end{array}$ \\
\hline AA-LT & $2.90 \pm 0.17$ & $2.95 \pm 0.39$ & $3.67 \pm 0.14$ & $\begin{array}{c}2.05 \pm 0.12 \\
(79.23)\end{array}$ & $\begin{array}{c}2.16 \pm 0.22 \\
(73.55)\end{array}$ & $\begin{array}{c}2.56 \pm 0.06 \\
(74.96)\end{array}$ & ND & ND & $\begin{array}{c}1.41 \pm 0.12 \\
(4.12)\end{array}$ \\
\hline
\end{tabular}

SW: Source seawater; CLT: Control larval tanks; AA-LT: AA-enriched larval tanks; ND: not detected 
Table 3 Concentrations of total free bacteria (TB) and bacteria with high (HNA) and very high (VHNA) nucleic acid contents in rotifer culture water.

\begin{tabular}{|c|c|c|c|c|c|c|c|c|c|}
\hline \multirow[b]{2}{*}{ Sample } & \multicolumn{3}{|c|}{$\begin{array}{c}\text { TB } \\
\left(\times 10^{9} \text { bacteria.ml }^{-1}\right)\end{array}$} & \multicolumn{3}{|c|}{$\begin{array}{c}\text { HNA } \\
\left(\times 10^{9} \text { bacteria.ml }^{-1}\right) \\
(\% \text { HNA })\end{array}$} & \multicolumn{3}{|c|}{$\begin{array}{c}\text { VHNA } \\
\left(\times 10^{9} \text { bacteria.ml }^{-1}\right) \\
(\% \text { VHNA }) \\
\end{array}$} \\
\hline & Day 4 & Day 15 & Day 26 & Day 4 & Day 15 & Day 26 & Day 4 & Day 15 & Day 26 \\
\hline $\mathrm{CR}$ & $16.47 \pm 2.39$ & $20.44 \pm 12.56$ & $4.68 \pm 0.47$ & $\begin{array}{c}3.84 \pm 1.41 \\
(23.32)\end{array}$ & $\begin{array}{c}8.16 \pm 9.69 \\
(39.94)\end{array}$ & $\begin{array}{c}2.17 \pm 0.40 \\
(46.36)\end{array}$ & $\begin{array}{c}10.25 \pm 3.48 \\
(62.25)\end{array}$ & $\begin{array}{c}10.64 \pm 5.71 \\
(52.08)\end{array}$ & $\begin{array}{c}1.03 \pm 0.79 \\
(22.01)\end{array}$ \\
\hline AA-R & $13.46 \pm 6.36$ & $15.52 \pm 8.79$ & $3.77 \pm 0.20$ & $\begin{array}{c}2.85 \pm 2.21 \\
(21.15)\end{array}$ & $\begin{array}{c}6.04 \pm 4.89 \\
(38.93) \\
\end{array}$ & $\begin{array}{c}1.72 \pm 0.29 \\
(45.58)\end{array}$ & $\begin{array}{c}7.91 \pm 3.57 \\
(58.74)\end{array}$ & $\begin{array}{c}6.89 \pm 2.63 \\
(44.42) \\
\end{array}$ & $\begin{array}{c}1.91 \pm 0.32 \\
(50.67)\end{array}$ \\
\hline
\end{tabular}

CR: Control rotifers; AA-R: AA-enriched rotifers. 


\section{Figure captions}

Figure 1 Flow cytometric dot-plots (FL1/SSC) of source seawater and culture water sampled in larval tanks. Reference beads of $1 \mu \mathrm{m}$ diameter (1), HNA subpopulation (2), LNA subpopulation (3), and VHNA subpopulation (4) are indicated.

Figure 2 Flow cytometric dot-plots (FL1/SSC) of culture water sampled in rotifer tanks. Reference beads of $1 \mu \mathrm{m}$ diameter (1), HNA subpopulation (2), LNA subpopulation (3), and VHNA subpopulation (4) are indicated.

Figure 3 Dendrogram of the DGGE fingerprint patterns of the microbial community showing the distance between bacterial communities from day 0 to 26 in larval rearing water and rotifer cultures. SW: source seawater (sampled before being added to larval tanks); AA: water in AA-enriched larval tanks; AAR: water in AA-enriched rotifer tanks; CT: water in control larval tanks; and CTR: water in rotifer tanks; d: sampling day. The cluster analaysis was based on Jaccard coefficient similarity indices and constructed using the Phoretix 1D Pro software (Nonlinear Dynamics, Newcastle upon Tyne, UK).

Figure 4 A) CFU counts on TCBS in control and AA-enriched larval tanks. B) CFU counts on TCBS in rotifer tanks. Counts are expressed as CFU.ml ${ }^{-1} \pm$ SD. Different letters indicate significant differences among sampling times or diets. 
Figure 1
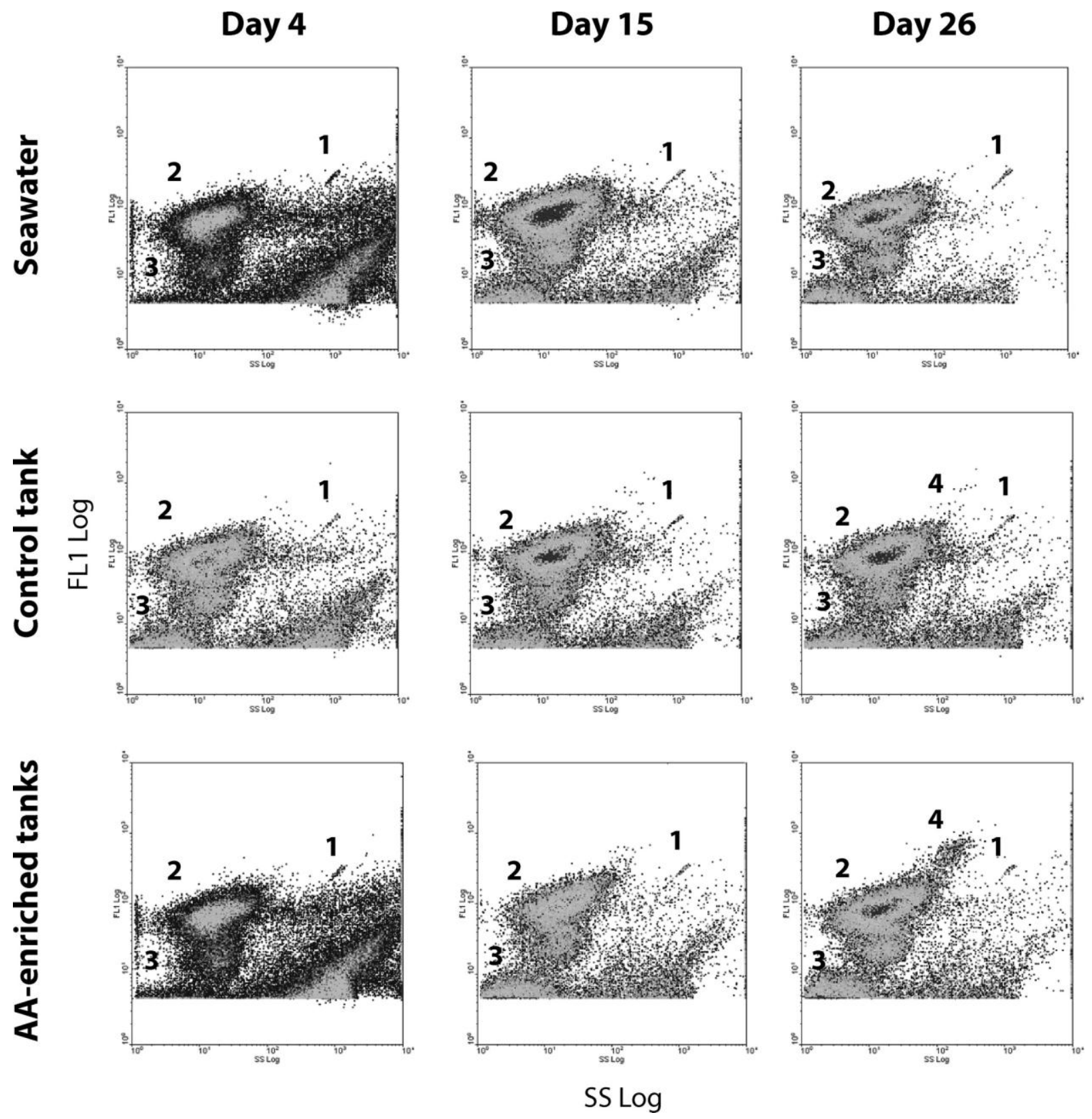
Figure 2

Day 4
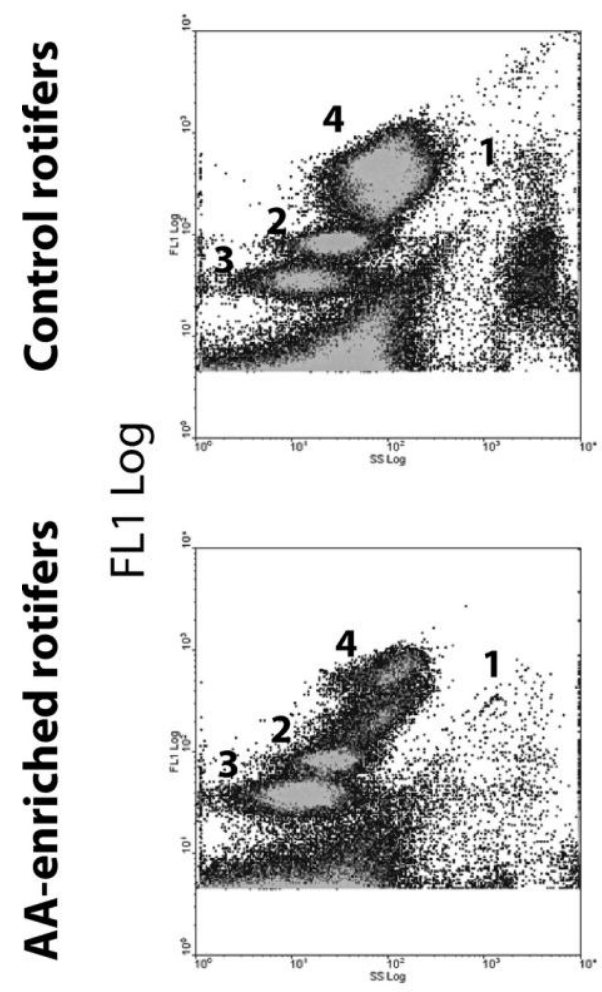

Day 15
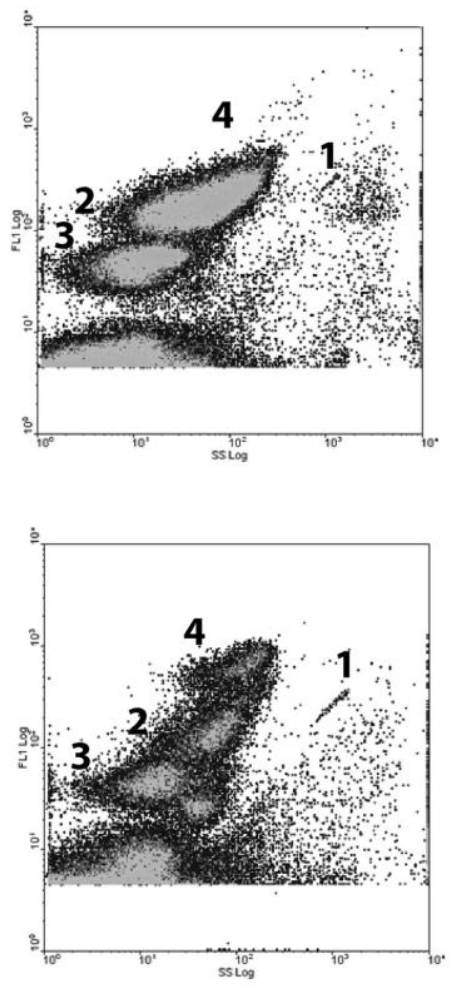

SS Log
Day 26
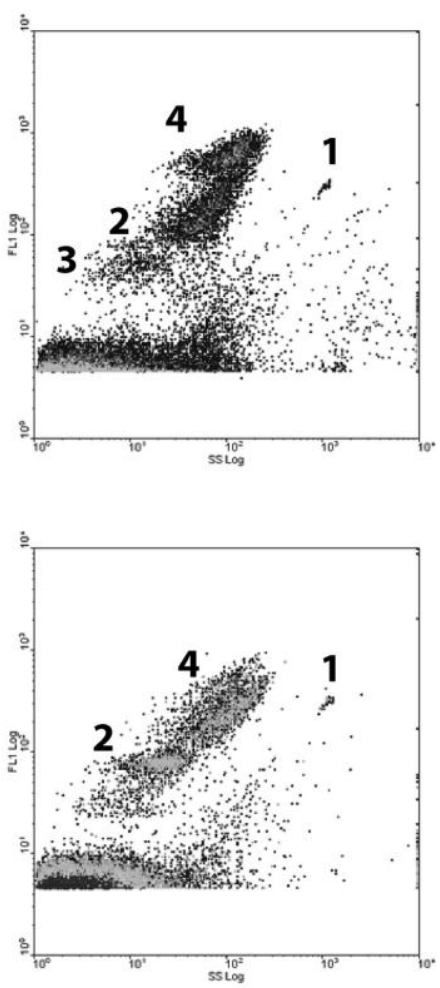

Figure 3

\section{Distance}

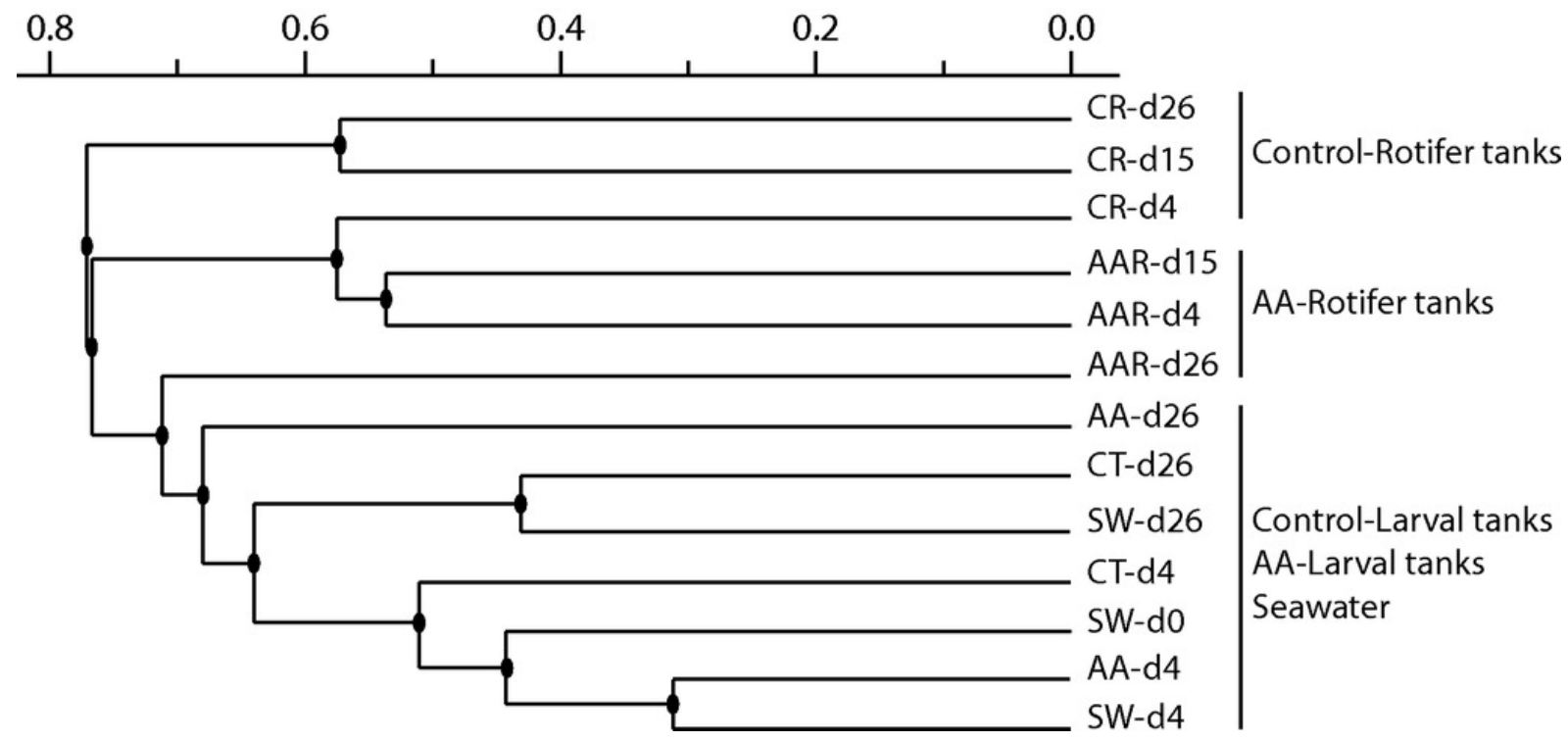


Figure 4
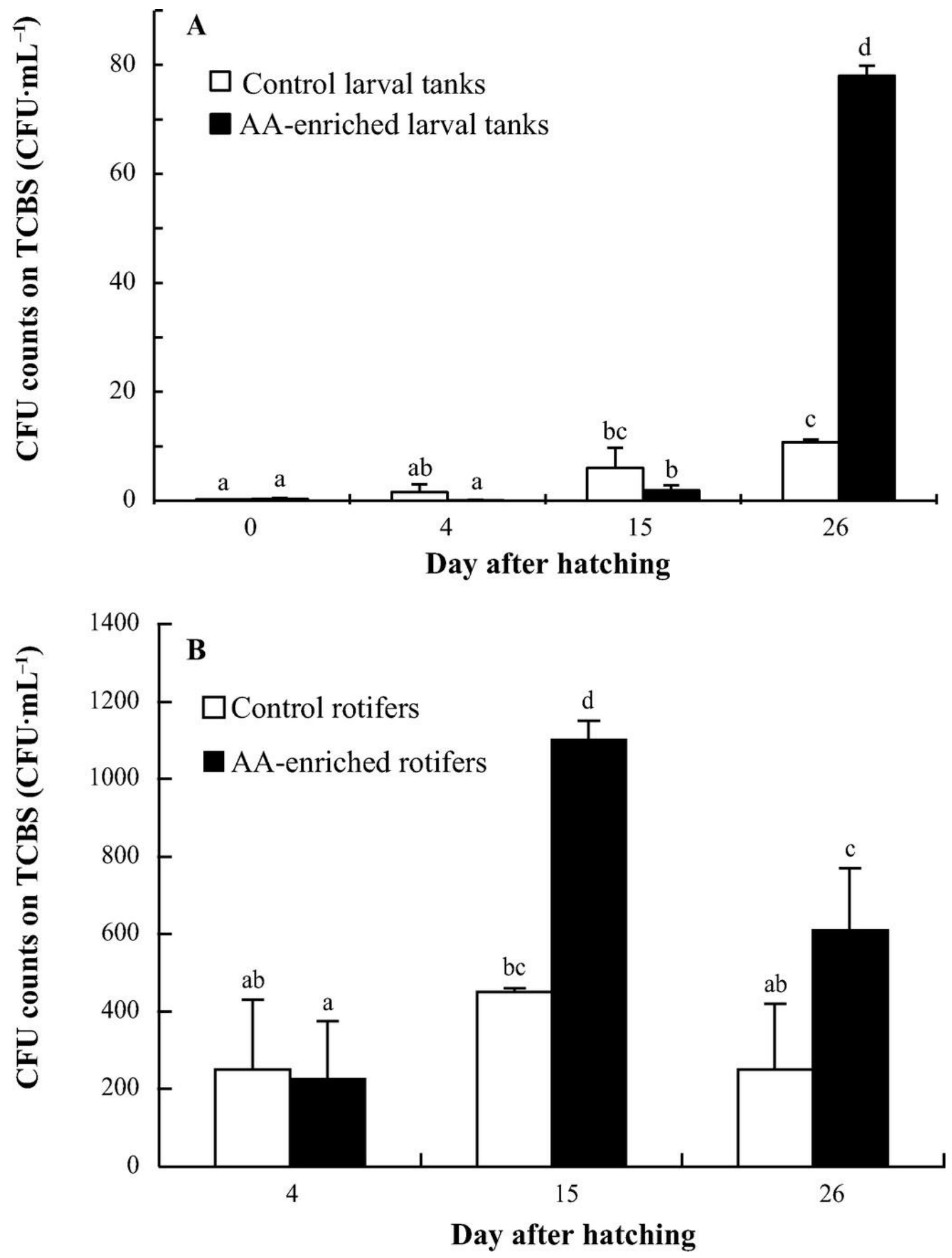